\title{
Studies on the Metabolic Fate of Cabergoline (III): Identification of Liver Metabolites, Distribution of Brain, and Effect on Hepatic Drug-Metabolizing Enzymes in Rats
}

\author{
Yasumasa GotoH, Masaharu MiYagi, Shunji NaKamuRA, \\ Masahiko NishiYAMA, and Arao UjIIE \\ Pharmacokinetics Laboratories, Research and Development, \\ Kissei Pharmaceutical Co., Ltd., Nagano
}

\begin{abstract}
Summary: The metabolites of cabergoline in liver were investigated in rats after a single oral administration. The identification was performed by HPLC and mass spectrometry equipped with an APCI interface. In addition to cabergoline, the identified metabolites are FCE- 27395 which is the demethylated derivative of cabergoline and, possibly, one more demethylated of FCE-27395.

Analysis of the metabolites in liver after a single oral administration of $\left[{ }^{14} \mathrm{C}\right]$-cabergoline $(0.5 \mathrm{mg} / \mathrm{kg})$ showed a difference in the content of the metabolites between male and female rats. This sexual difference was due to the much higher content in FCE-27395 in male rat liver compared to female rat liver. For both sexes the major metabolite was FCE-27395, and other metabolites were found in minor quantities.

The consecutive administration of cabergoline did not cause any induction of hepatic drug metabolizing enzymes, such as cytochrome P450, cytochrome b5, aniline hydroxylase, and aminopyrine demethylase.

The distribution in the brain after a single intravenous administration of $\left[{ }^{3} \mathrm{H}\right]$-cabergoline $(0.5 \mathrm{mg} / \mathrm{kg})$ was also investigated. The collected tissues were cerebral cortex, striatum, and hypophysis. The highest radioactivity was in the hypophysis, in which tissue the radioactivity tended to remain until 24 hour after dosing. Most of the radioactivity in these tissues could be attributed to cabergoline, as there were only traces of its metabolites.
\end{abstract}

Key words: Cabergoline, FCE-27395, Metabolite, APCI LC/MS, Liver, Brain, Rat

\section{Introduction}

Cabergoline, 1-[(6a $R, 9 R, 10 \mathrm{a} R)-7-$ allyl-4,6,6a $, 7,8,9$, $10,10 \mathrm{a}-$ octahydroindolo- $[4,3-f g]$ quinoline- 9 -carbonyl]-1-(3-dimethylaminopropyl)-3-ethylurea, an ergot alkaloid synthesized by Pharmacia S. p. A., Italy, has been shown to be a potent and selective agonist of D2dopamine receptors and to have long-lasting inhibitory effects on prolactin secretion and antiparkinsonian activity in humans and animals. ${ }^{1-7)}$

The metabolism of cabergoline in rat urine was reported in 1993 by Battaglia et al, ${ }^{8}$ ) but the metabolites were not analyzed in rat liver, which organ was observed to have a high level of distribution. Therefore, the purpose of this study was to investigate the metabolism of cabergoline in rat liver and to identify any new metabolites. And the concentration of cabergoline and its metabolites in liver and brain which is rich in pharmacological receptors, was investigated . Separate enzyme induction studies were performed with unlabelled cabergoline.

\section{Materials and Methods}

\section{Materials}

$\left[{ }^{14} \mathrm{C}\right]$-cabergoline was synthesized by Nemoto \& Co., Ltd. Its specific activity was $890 \mathrm{MBq} / \mathrm{mmol}$ and radiochemical purity was $98.0 \%$ as judged by TLC methods. $\left[{ }^{3} \mathrm{H}\right]$-cabergoline was synthesized by Amersham Co., Ltd. the specific activity was $1.30 \mathrm{TBq} / \mathrm{mmol}$ and radiochemical purity, $95.0 \%$ as judged by TLC methods (Fig. 1).

Unlabelled cabergoline, FCE-21589 (6-allyl-8b-carboxy-ergoline) and FCE-27395 (N-(3-methylaminopropyl)-N-ethylaminocarbonyl-[6-(2-propenyl)-ergoline-8b]-carboxamide) were supplied by Chemical Development Department of Pharmacia S. p. A., Italy (Fig. 1).

Other chemicals and solvents were of analytical grade and were obtained from various suppliers.

\section{Animals and Dosage}

Male and female Sprague Dawley rats weighting 200$300 \mathrm{~g}$ were purchased from SLC, Shizuoka, Japan. The rats were housed in temperature- and humidity-con- 
Cabergoline

$\left({ }^{3} \mathrm{H},{ }^{14} \mathrm{C}\right)$<smiles>CCNC(=O)N(CCCN(C)C)C(=O)[C@H]1C[C@@H]2c3cccc4[nH]cc(c34)C[C@H]2N(C/C=C/c2ccccc2)C1</smiles>

FCE-27395<smiles>C=CCN1C[C@H](C(=O)N(CCCNC)C(=O)NCC)C[C@@H]2c3cccc4[nH]cc(c34)C[C@H]21</smiles>

FCE-21589

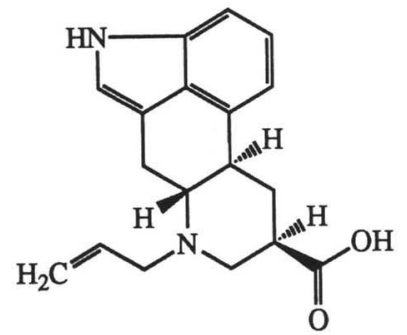

FCE-27392<smiles>CCNC(=O)N(CCCN(C)C)C(=O)[C@@H]1CN[C@H]2Cc3c[nH]c4cccc(c34)[C@H]2C1</smiles>

FCE-21590<smiles>C=CCN1C[C@H](C(=O)NCCCN(C)C)C[C@@H]2c3cccc4[nH]cc(c34)C[C@H]21</smiles>

FCE-27391

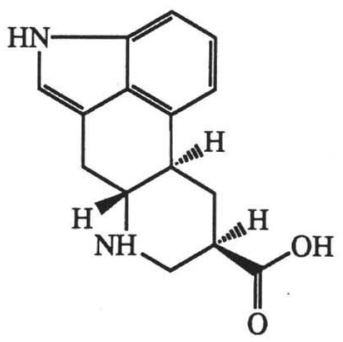

Fig. 1 Chemical structure and labeled position of $\left[{ }^{14} \mathrm{C}\right]$ and $\left[{ }^{3} \mathrm{H}\right]$ cabergoline and chemical structure of authentic samples

trolled rooms $\left(22 \pm 1^{\circ} \mathrm{C}\right.$ and $60 \pm 10 \%$ humidity) with a 12-hour light 12-hour dark cycle. The animals were fed laboratory chow (CE-2, Clea Inc.) and provided water ad libitum, but they were starved overnight before and 4 hours after dosing. Cabergoline was suspended in $0.5 \%$ methylcellulose (Wako Pure Chemicals Co., Ltd.) and was administered orally at a dose of $10 \mathrm{mg} / 5 \mathrm{ml} / \mathrm{kg}$ of cabergoline in the study of the identification of liver metabolites or at a dose of $985 \mathrm{kBq} / 0.5 \mathrm{mg} / 5 \mathrm{ml} / \mathrm{kg}$ of $\left[{ }^{14} \mathrm{C}\right]$-cabergoline in the analytical study of the liver metabolites by gastric gavage. The intravenous dose given to the rats was $1.44 \mathrm{GBq} / 0.5 \mathrm{mg} / 2 \mathrm{ml} / \mathrm{kg}$ of $\left[{ }^{3} \mathrm{H}\right]$-cabergoline dissolved in aqueous phosphoric acid and saline.

In the study of the effect on hepatic drug-metabolizing enzymes unlabelled cabergoline was administered orally as a suspension in $0.5 \%$ methylcellulose at daily doses of $0.05,0.1,0.5$, and $1.0 \mathrm{mg} / 5 \mathrm{ml} / \mathrm{kg}$ for 7 days. The control group was treated with the same volume of the vehicle, i.e., $0.5 \%$ methylcellulose, for 7 days. Phenobarbital-Na (Analytical grade, Wako Pure Chemicals Co., Ltd.) as positive control was administered intraperitoneally at a dose of $80 \mathrm{mg} / \mathrm{ml} / \mathrm{kg} /$ day for 4 days.

\section{Identification of Liver Metabolites}

Sample preparation: At 4 hours after oral administration of unlabelled cabergoline, the rats were anesthetized with ether and sacrificed by exsanguination from the abdominal aorta. The liver was excised and homogenized with $10 \mathrm{ml}$ of $1 / 15 \mathrm{M}$ phosphate-buffered isotonic saline ( $\mathrm{pH} \mathrm{7.4)}$. After the addition of $30 \mathrm{ml}$ of acetonitrile, the mixture was shaken for 30 minutes and centrifuged at $3000 \mathrm{rpm}$ for $10 \mathrm{~min}$. The resulting supernatant was evaporated to dryness, and the sample was redissolved in the HPLC mobile phase.

Apparatus: The HPLC system (L-7000 series, Hitachi), equipped with a UV source $(225 \mathrm{~nm})$ and a reversed phase column (Inertsil $\mathrm{C}_{8}, 4.6 \times 250 \mathrm{~mm}$ or $4.6 \times 150 \mathrm{~mm}$, GL Science), was operated with $0.1 \%$ trifluoroacetic acid (TFA)/acetonitrile (87/13) as the mobile phase. The flow rate of the mobile phase was 1.0 $\mathrm{ml} / \mathrm{min}$, and column temperature was at the ambient room temperature.

Mass spectra were obtained with a Hitachi M-2000 A double-focusing mass spectrometer equipped with an atmospheric pressure chemical ionization (APCI) interface and an L-6200 pump (Hitachi). The flow rate of the mobile phase was set to $1.0 \mathrm{ml} / \mathrm{min}$. Nebulization heater temperature and desolvation heater temperature were set at $420^{\circ} \mathrm{C}$ and $330^{\circ} \mathrm{C}$, respectively; and drift voltage and electron multiplier voltage, at $80 \mathrm{~V}$ and $1500 \mathrm{~V}$, respectively.

\section{Analysis of the Liver Metabolites}

Sample preparation: At $0.25,0.5,2,4,8$, and 24 
hours after oral administration of $\left[{ }^{14} \mathrm{C}\right]$-cabergoline to male and female rats, the liver was prepared by the same methods as used for the identificatin of metabolites. The dried sample was redissolved in cold $0.1 \%$ phosphoric acid/acetonitrile (1/4) and centrifuged at $3000 \mathrm{rpm}$ for $10 \mathrm{~min}$. The organic phase was analyzed by TLC.

TLC analysis: The TLC plates were silicagel 60 F254 $(0.25 \mathrm{~mm}, 20 \times 20 \mathrm{~cm}$, Merck). The developing solvent system was chloroform/methanol/30\% ammonium hydroxide, $70 / 30 / 1$ by volume. Radioactivity was quantified with a radiochromanizer JTC-601 (Aloka Co. Ltd.).

The labeled metabolites were identified by comparison with standard reference compounds co-chromatographed with each analyzed sample. The standard reference compounds were observed under UV lamp illumination at $254 \mathrm{~nm}$.

\section{Effect on Hepatic Drug-metabolizing Enzymes}

At day one after the final dose, the rats were killed by decapitation, and their livers were perfused with chilled saline. Then, each liver was quickly removed, weighed, and homogenized in ice-cold $1 \mathrm{mM}$ EDTA-10 $\mathrm{mM}$ phosphate buffer ( $\mathrm{pH} 7.4$ ) containing $1.15 \% \mathrm{KCl}$ in a homogenizer with a Teflon pestle. The homogenate was centrifuged at $9000 \times \mathrm{g}$ for $20 \mathrm{~min}$ at $4^{\circ} \mathrm{C}$, and the obtained supernatant was then centrifuged at $105,000 \times \mathrm{g}$ for $60 \mathrm{~min}$ at $4^{\circ} \mathrm{C}$. The resulting pellet was suspended in $1 \mathrm{mM}$ EDTA-10 mM phosphate buffer ( $\mathrm{pH} 7.4$ ) for assaying cytochrome $\mathrm{P} 450$ and b5 contents by the method of Omura et al. ${ }^{9)}$ The protein content was determined by the BCA method ${ }^{10}$ ) using bovine serum albumin as a standard. The determination of the activity of aniline hydroxylase and of aminopyrine demethylase was made by the method of Imai et al. ${ }^{11)}$ and Nash ${ }^{12)}$, respectively. UV observation was performed with a U-3200 double beam spectrophotometer (Hitachi).

Data are expressed as the mean and the standard error of 6 to 8 animals, and the results are analyzed for statistical significance with multiple comparison which compared with a vehicle using Dunnett's test.

\section{Metabolism of Aminopyrine}

Using liver microsomes of control male rats, we measured the remaining aminopyrine concentration with or without unlabeled cabergoline. The fixed concentration of aminopyrine $(0.16 \mathrm{mM}, 100 \mu \mathrm{l})$ and the several concentration of cabergoline added to control liver microsomes $(8.4 \mathrm{mg} / \mathrm{ml}, 30 \mu l)$ incubated at $37^{\circ} \mathrm{C}$ for $1 \mathrm{hr}$ $(n=1)$. The mixture added to equal volume of acetonitrile to remove the protein, then mixed and centrifuged at 3,000 rpm for $10 \mathrm{~min}$. The aminopyrine concentration in the resulting supernatant was determined directly by HPLC under the same conditions as described for the identification of liver metabolites.

\section{Analysis of the Brain Metabolites}

At 4,8 , and 24 hours after intravenous administration of $\left[{ }^{3} \mathrm{H}\right]$-cabergoline, male rats were anesthetized with ether and sacrificed by exsanguination from the abdominal aorta. The brain was dissected from each rat and divided into cerebral cortex, striatum, and hypophysis. Like regions from three rats pooled and deproteinized with acetonitrile. Plasma and a part of the organic phase of the tissue extracts were directly analyzed with a liquid scintillation counter (Tri-Carb 1900CA, Packard). The rest of the organic phase was delivered as $400 \mu l$ fractions into a microplate by an HPLC equipped with a fraction collector (Model 201, Gilson). The radioactivity was then measured in a microplate scintillation counter (Top Count, Packard).

\section{Results}

\section{Identification of Liver Metabolites}

As shown in Fig. 2, two major and several minor peaks were found in the HPLC chromatogram of the extract from rat liver at 4 hours after oral dosing with cabergoline. The unknown peaks were named P1, P2, and P3 in reverse order of elution from the HPLC. These were identified by APCI LC/MS and HPLC. The structure assignment was based on the molecular mass of the $\mathrm{m} / \mathrm{z}$ ions and the fragmentation pattern and is described below (Figs. 3-6).

P1: P1 in the extract from rat liver was eluted with the same retention time as the standard cabergoline (Fig. 2). In the APCI LC/MS spectrum of P1, the peaks at $\mathrm{m} /$ z 452 and 381 corresponded to the ions $[\mathrm{M}+\mathrm{H}]^{+}$and $\left[\mathrm{M}-\mathrm{CONHC}_{2} \mathrm{H}_{5}+\mathrm{H}\right]^{+}$, respectively; the standard cabergoline showed the similar pattern (Figs. 3, 4).

$\mathrm{P} 2$ : $\mathrm{P} 2$ in the extract from rat liver was eluted with the same retention time as the standard FCE-27395 (Fig. 2). In the APCI LC/MS spectrum of $\mathrm{P} 2$, the peaks at $\mathrm{m} / \mathrm{z}$ 438 and 367 corresponded to the ions $[\mathrm{M}+\mathrm{H}]^{+}$and $\left[\mathrm{M}-\mathrm{CONHC}_{2} \mathrm{H}_{5}+\mathrm{H}\right]^{+}$, respectively; and the standard FCE-27395 showed the similar pattern (Figs. 4,5). The fragmentation pattern for FCE-27395 indicated the presence of the ethylaminocarbonyl moiety, as shown by the 71 amu fragment also present in the parent drug (Fig. 3).

P3: The HPLC profile showed the presence of a minor peak (Fig. 2), and a fragmentation pattern similar to the other two was obtained from the LC/MS spectrum of P3 with $\mathrm{m} / \mathrm{z}$ at 424 and 353 . The characteristic loss of 71 amu from the protonated molecular ion yielded a fragment ion corresponding to the ions $\left[\mathrm{M}-\mathrm{CONHC}_{2} \mathrm{H}_{5}+\right.$ $\mathrm{H}]^{+}$. P3 is thought to be the N-de-methylation derivative of FCE-27395 because of the molecular ion peak at 424 corresponding to the loss of the methyl moiety as a 14 amu fragment from FCE-27395, just as FCE-27395 arose from cabergoline by N-de-methylation of the latter(Figs. 4, 6). 

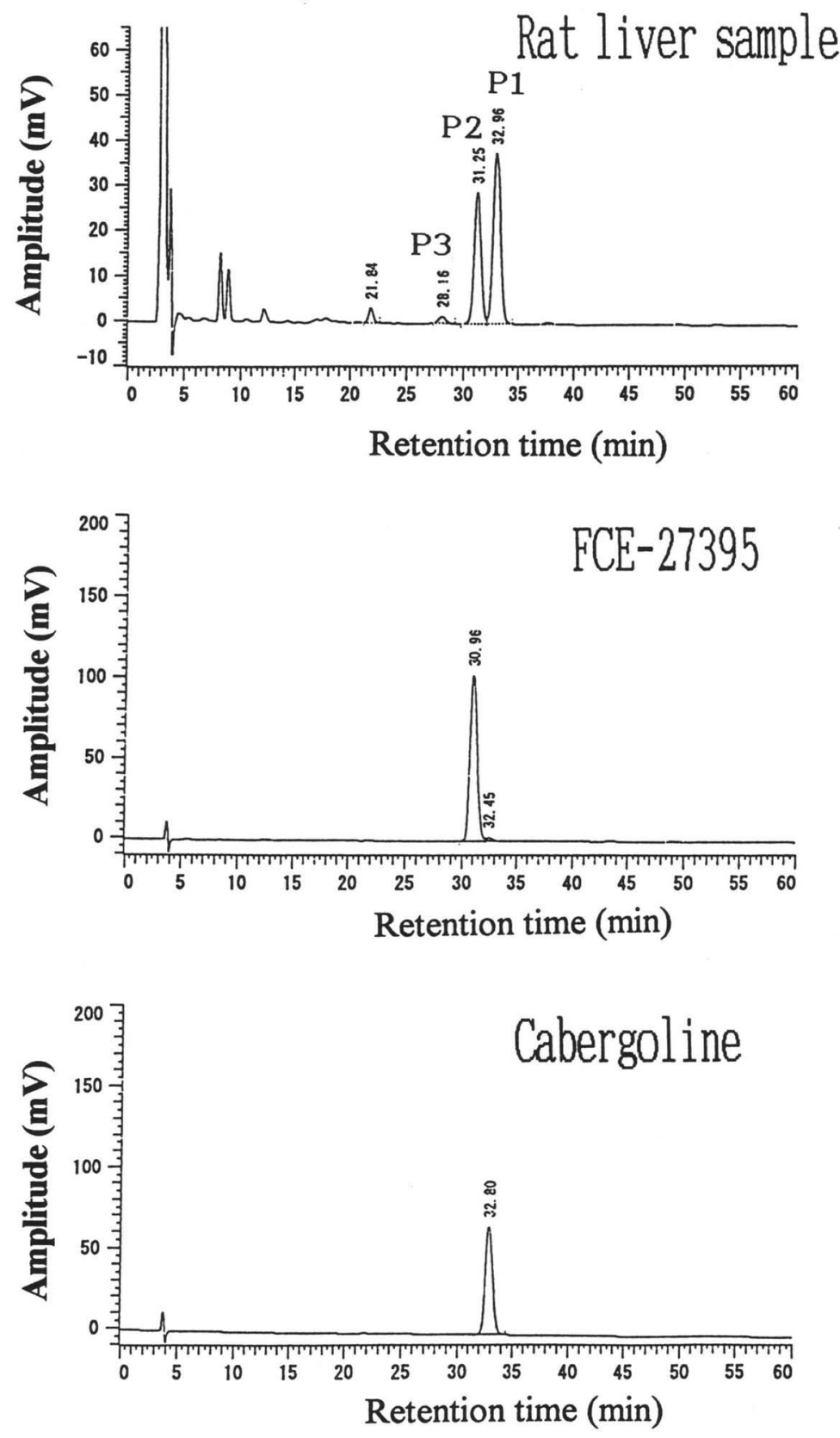

Fig. 2 HPLC chromatograms of the extract from rat liver 4 hour after oral administration of cabergoline (upper) and authentic standards of FCE-27395 (middle) and cabergoline (bottom).

\section{Analysis of the Liver Metabolites}

Tables I and II show the results of analysis of the composition of radioactivity in liver after a single oral administration of $\left[{ }^{14} \mathrm{C}\right]$ cabergoline to male or female rats $(0.5 \mathrm{mg} / \mathrm{kg})$. Data are expressed as radioactivity concentration and \% of radioactivity following TLC chromatographic analyses of extracts from male and female rat livers as described in Methods. The radioactivity concentration of cabergoline in male and female livers showed almost the similar pattern, but the total radioactivity concentration was different between the sexes because the radioactivity concentration of FCE-27395 in the male liver was higher than that in the female.
In male rat liver the composition of radioactivity consisted of cabergoline, FCE-27395, FCE-21589, and other metabolites. Cabergoline accounted for $70.0 \%$ of the radioactivity in the liver, the highest ratio found at 0.5 hours after dosing; then at 24 hours this ratio decreased to $21.1 \%$. Whereas the composition ratio of cabergoline in the liver tended to decrease following time, that of FCE-27395 tended to increase, reaching its highest ratio, $66.1 \%$, at 8 hours after dosing. The composition ratio of FCE-21589 was small from 0.25 to 24 hours $(1.1 \% \sim 7.2 \%)$; and others were, too $(5.2 \% \sim$ $15.1 \%)$.

In female rats the composition ratio of cabergoline 


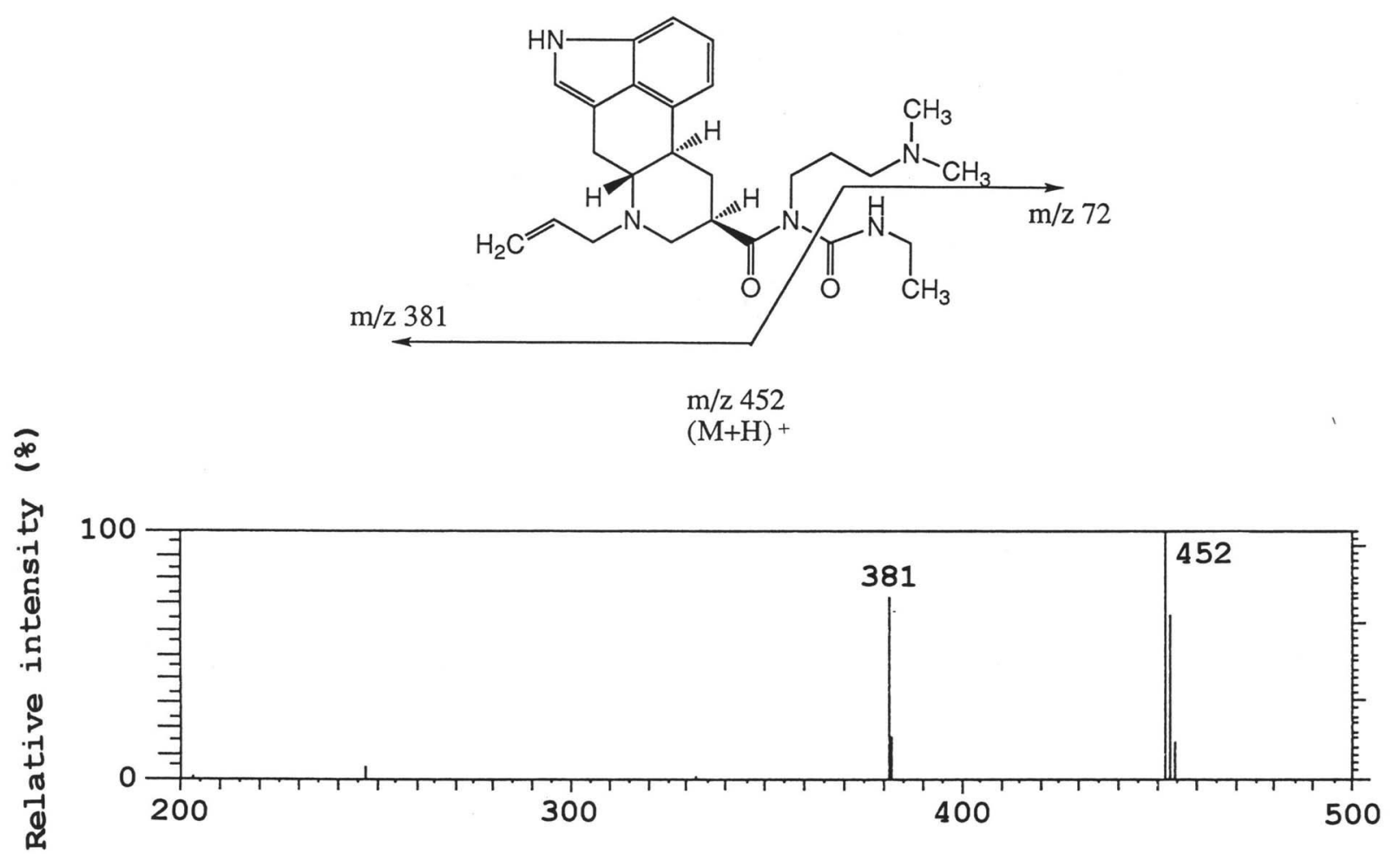

Fig. 3 Mass fragmentation of cabergoline and mass spectrum

was $80.5 \%$ of the radioactivity at 2 hours after dosing, which was the highest ratio; then at 24 hours it decreased to $25.7 \%$. On the other hand, the proportion of FCE-27395 (10.2\% 46.9\%) did not increase so much as observed for male rat liver, but FCE-27395 was considered to be the main metabolite in females also. The composition ratio of FCE-21589 was small from 0.25 to 24 hours $(0.5 \% \sim 4.7 \%)$; and others were likewise $(1.7 \% \sim 17.2 \%)$.

\section{Effect on Hepatic Drug-metabolizing Enzymes}

The hepatic protein contents and enzyme activities obtained after 7 days of treatment with cabergoline or after 4 days of treatment with phenobarbital as a reference compound are presented in Table III . The body weight in cabergoline-treated animals tended to decrease of the increment of the body weight and the liver weight in cabergoline-treated animals tended to decrease compared with those of the control group. The hepatic cytochrome P450 contents were not significantly different from the control group value. A significant increase in the hepatic cytochrome b5 content was observed at $0.05 \mathrm{mg} / \mathrm{kg}$ dosing, but the change was not dose dependent. The aniline hydroxylase activity was not significantly different from that of the control group. The aminopyrine demethylase activity tended to decrease following the dose increase; especially, the activity for the $1 \mathrm{mg}$ / $\mathrm{kg}$ cabergoline-treated group was significantly lower than the control activity.

The hepatic protein contents and enzyme activities in the phenobarbital-treated group were significantly in- creased over those of the control group, but the body and liver weight were not significantly different.

\section{Metabolism of Aminopyrine}

The effect of various concentration of cabergoline on the aminopyrine metabolizing activity of control liver microsomes is shown in Fig. 7. Several concentrations of cabergoline were incubated with a fixed concentration of aminopyrine in control liver microsomes at $37^{\circ} \mathrm{C}$ for 1 hour. The vertical axis shows the remaining aminopyrine concentration, and the horizontal axis shows the molar ratio of cabergoline to aminopyrine. The remaining aminopyrine concentration tended to be increased following an increase in the molar ratio of cabergoline to aminopyrine. That is, the metabolism of aminopyrine was concentration-dependently inhibited by cabergoline.

\section{Analysis of the Brain Metabolites}

Table IV shows the tissue distribution of radioactivity and Fig. 8 shows a chromatogram of $\left[{ }^{3} \mathrm{H}\right]$ labeled compounds in extracts of cerebral cortex, striatum, and hypophysis prepared at 4,8 , and 24 hours after a single intravenous administration of $\left[{ }^{3} \mathrm{H}\right]$-cabergoline. The concentration of radioactivity in the cerebral cortex was nearly the same as that in the plasma. And the ${ }^{3} \mathrm{H}$ concentrations in the striatum and hypophysis were higher than the concentration in the cerebral cortex, being from 2.3-fold to 2.9-fold and from 43-fold to 70-fold, respectively. Since the total concentration of $3 \mathrm{H}$ was different among cerebral cortex, striatum, and hypophysis, we in- 
Time (min)
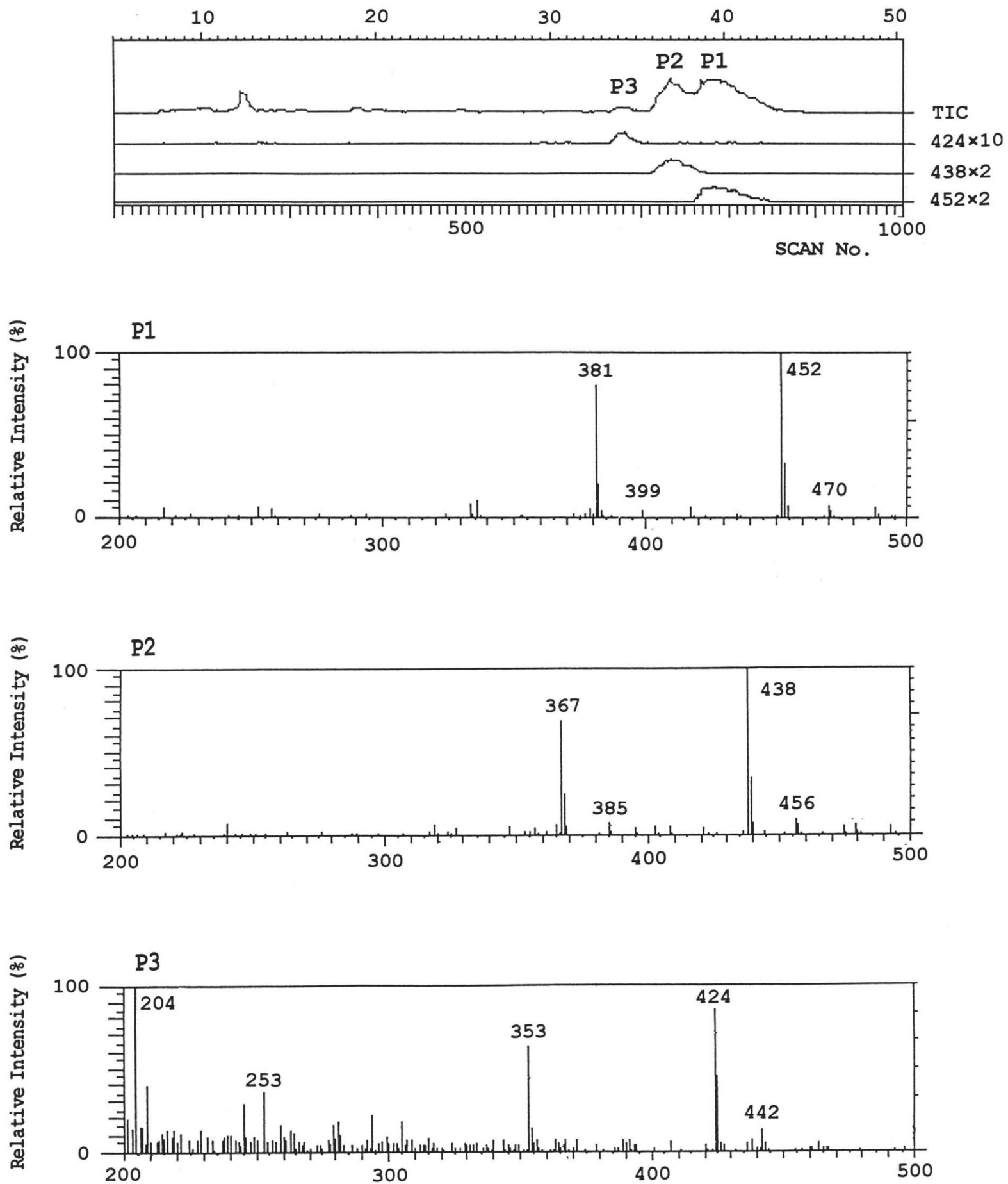

Fig. 4 APCI LC/MS chromatogram of an extract of rat liver 4 hours after oral administration of cabergoline and mass spectrum of P1, P2 and P3.

vestigated the composition of the metabolites in the tissues. The main peak observed for each tissue at all points was cabergoline, and only traces of any of its metabolites were found (Fig. 8).

\section{Discussion}

Analysis of the urinary metabolites after oral adminis- tration of $\left[{ }^{14} \mathrm{C}\right]$-cabergoline to rats has already been made. ${ }^{8)}$ The major urinary metabolites found was the acid derivative FCE-21589. And other minor metabolites were FCE-27391 (the 6-deallyl-derivative of the acid FCE-21589), FCE-21590 (the deethylisocyanate of cabergoline) and FCE-27392 (the 6-deallylcabergoline) (Fig. 1). From these results, it is evident that 


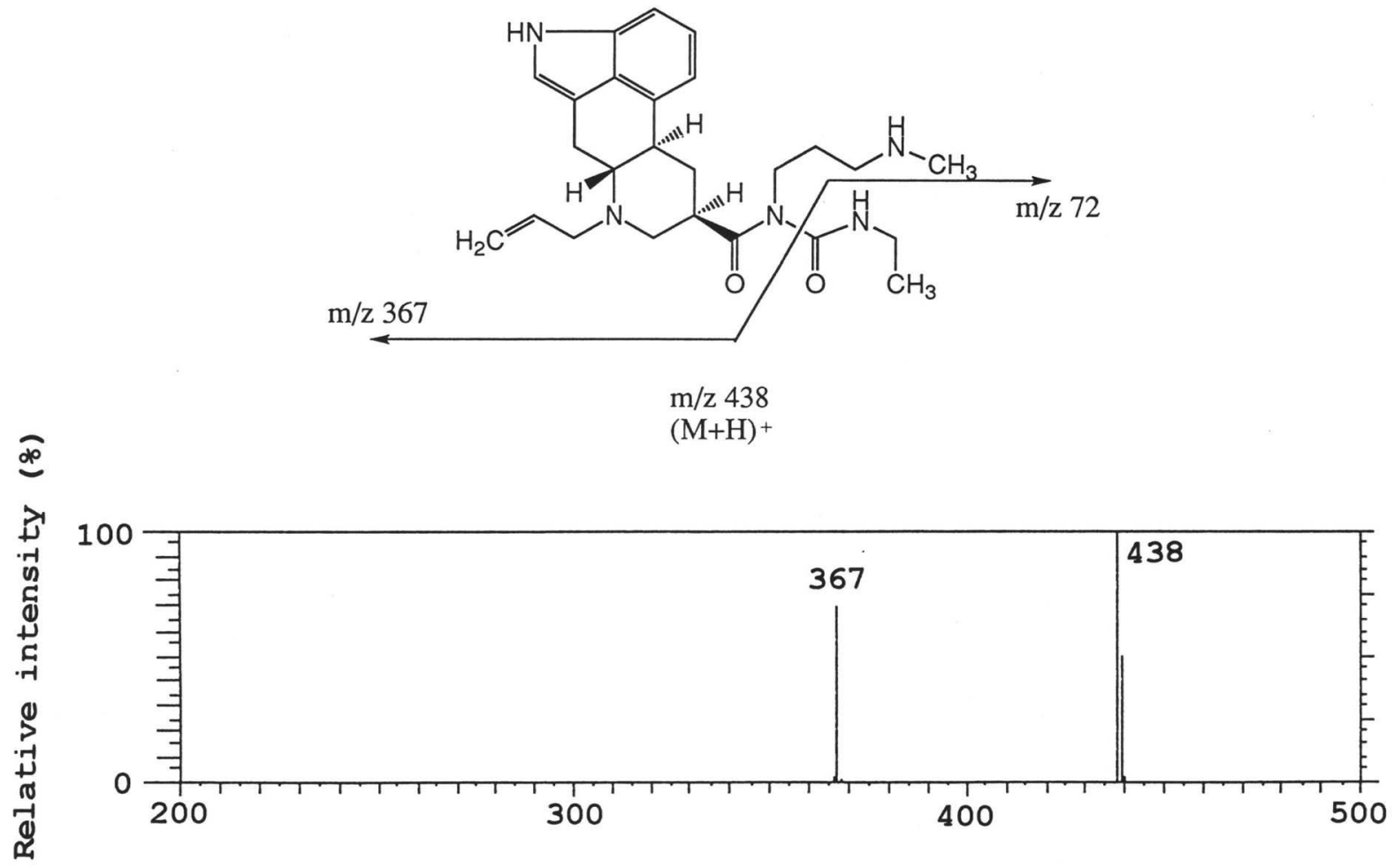

Fig. 5 Mass fragmentation of FCE-27395 and mass spectrum<smiles>C=CCN1C[C@H](C(=O)N(CCCN)C(=O)NCC)C[C@@H]2c3cccc4[nH]cc(c34)C[C@H]21</smiles>

Fig. 6 Postulated structure of P3

hydrolysis rather than oxidation was the major biotransformation pathway for cabergoline in rats. On the other hand, we confirmed two new metabolites (FCE-27395 and the demethyl-derivative of FCE-27395 (P3)), unchanged cabergoline, and only traces of other metabolites in rat liver after oral administration of cabergoline. In this study, FCE-27395 was the major metabolite in rat liver, and was of equal importance with cabergoline. FCE-27395 was not detected in the urine of some animal species. FCE-27395 is likely to arise from oxidative $\mathrm{N}$-demethylation of cabergoline by hepatic enzyme like cytochrome $\mathrm{P} 450$, and the similar reaction may occur to form the de dimethylated metabolite (P3) from FCE-27395 in rat liver. Therefore, other metabolites

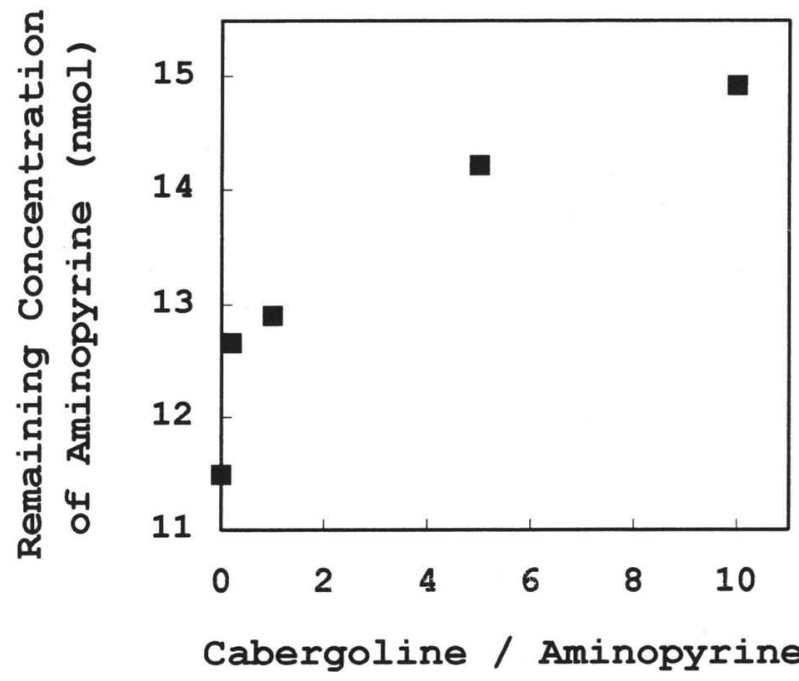

Fig. 7 Effect of cabergoline on the aminopyrine metabolizing activity of control liver microsomes incubated at $37^{\circ} \mathrm{C}$ for 1 hour. The vertical axis shows the remaining aminopyrine concentration, and the horizontal axis shows the molar ratio of cabergoline to aminopyrine.

such as FCE-27391 and FCE-21589 found in rat urine ${ }^{8)}$ might be generated outside the liver by further degradation of cabergoline and/or FCE-27395.

Since the metabolites formed in the liver agreed with the standards in the point of their molecular weight and retention time of HPLC, the metabolites did not involve 
$4 \mathrm{~h}$

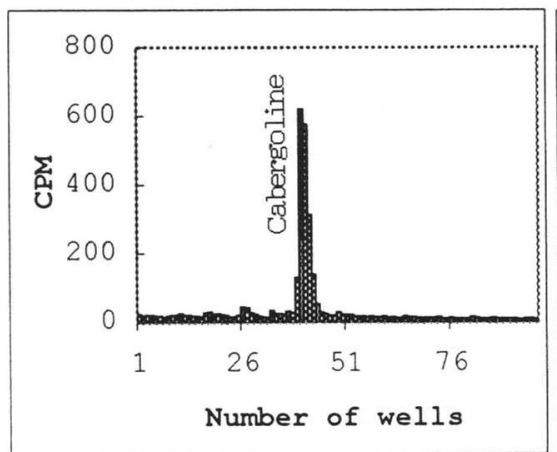

$8 \mathrm{~h}$
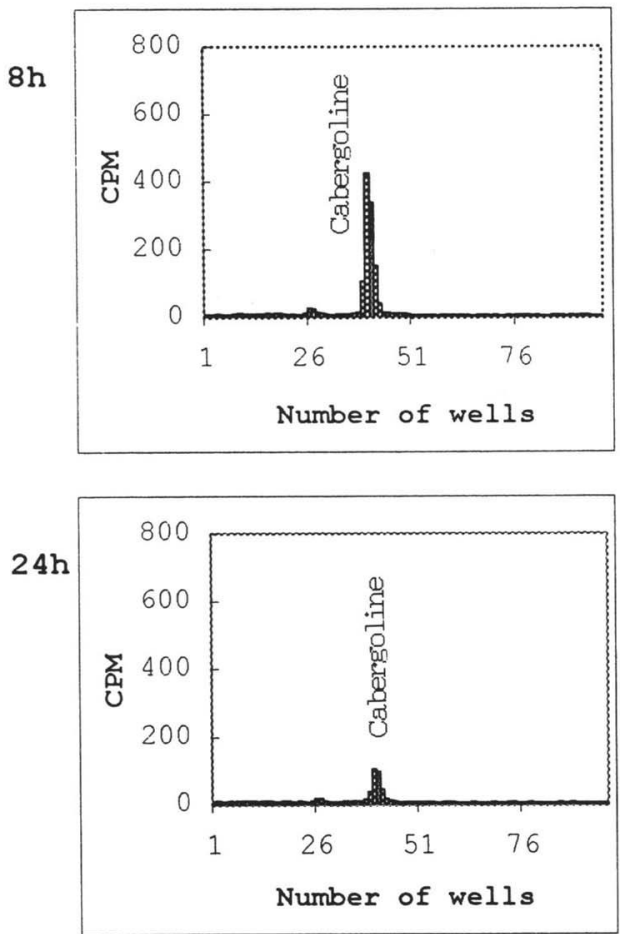

Frontal Cortex
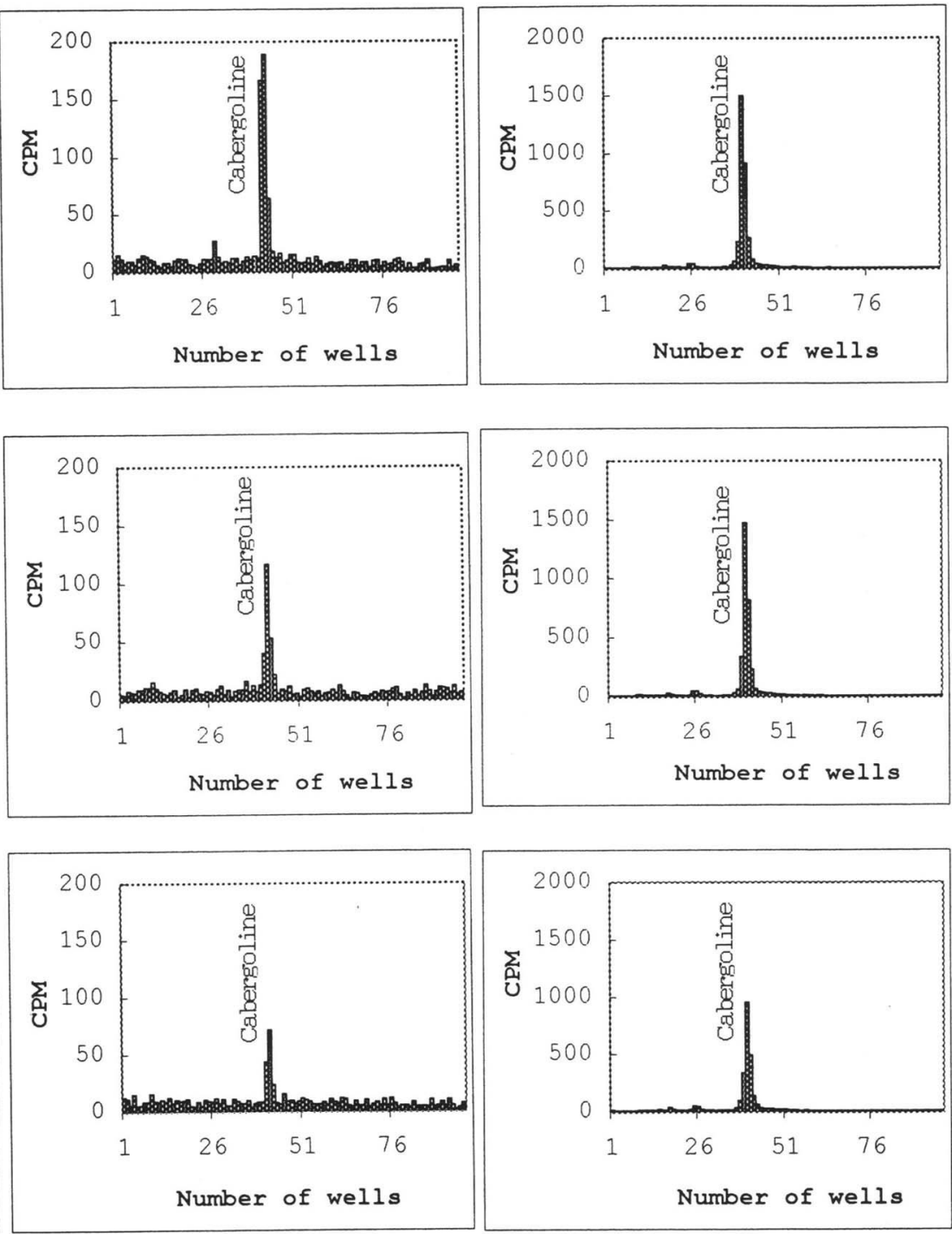

Striatum

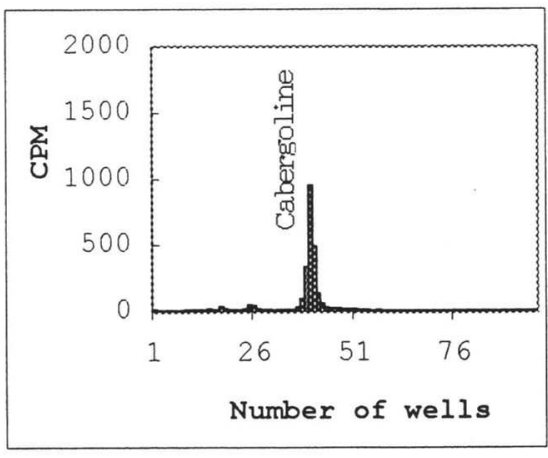

Hypophysis

Fig. 8 Chromatogram of radioactivity in cerebral cortex, striatum, and hypophysis at 4, 8, and 24 hours after a single intravenous administration of $\left[{ }^{3} \mathrm{H}\right]$ cabergoline to male rats $(0.5 \mathrm{mg} / \mathrm{kg})$.

Table I Composition of radioactivity in liver after a single oral administration of $\left[{ }^{14} \mathrm{C}\right]$ cabergoline to male rats $(0.5 \mathrm{mg} / \mathrm{kg})$

\begin{tabular}{|c|c|c|c|c|c|}
\hline \multirow{2}{*}{$\underset{(\mathrm{hr})}{\operatorname{Time}}$} & \multicolumn{5}{|c|}{$\begin{array}{l}\text { Radioactivity concentration (ng/eq. of cabergoline/g) } \\
\text { (\% of radioactivity) }\end{array}$} \\
\hline & Total & Cabergoline & FCE-27395 & FCE-21589 & others \\
\hline 0.25 & $\begin{array}{l}1011.1 \pm 132.6 \\
(100)\end{array}$ & $\begin{array}{l}605.1 \pm 88.8 \\
(63.7 \pm 2.9)\end{array}$ & $\begin{array}{l}188.6 \pm 11.9 \\
(20.5 \pm 2.5)\end{array}$ & $\begin{array}{l}12.1 \pm 3.5 \\
(1.3 \pm 0.2)\end{array}$ & $\begin{array}{l}78.2 \pm 14.0 \\
(8.3 \pm 0.8)\end{array}$ \\
\hline 0.5 & $\underset{(100)}{2042.9 \pm 93.3}$ & $\begin{array}{c}1341.6 \pm 119.4 \\
(70.0 \pm 3.1)\end{array}$ & $\begin{array}{l}361.4 \pm 26.4 \\
(18.9 \pm 1.0)\end{array}$ & $\begin{array}{l}20.5 \pm 4.6 \\
(1.1 \pm 0.3)\end{array}$ & $\begin{array}{r}124.8 \pm 37.8 \\
(6.7 \pm 2.2)\end{array}$ \\
\hline 2 & $\begin{array}{l}1845.7 \pm 503.0 \\
(100)\end{array}$ & $\begin{array}{l}877.1 \pm 193.2 \\
(52.8 \pm 3.6)\end{array}$ & $\begin{array}{l}677.8 \pm 185.6 \\
(39.1 \pm 1.1)\end{array}$ & $\begin{array}{l}18.9 \pm 16.3 \\
(1.2 \pm 0.9)\end{array}$ & $\begin{array}{r}108.4 \pm 63.1 \\
(5.2 \pm 2.2)\end{array}$ \\
\hline 4 & $\begin{array}{l}2418.6 \pm 160.4 \\
(100)\end{array}$ & $\begin{array}{l}901.2 \pm 165.8 \\
(39.2 \pm 4.9)\end{array}$ & $\begin{array}{c}1075.7 \pm 81.5 \\
(47.6 \pm 2.3)\end{array}$ & $\begin{array}{l}59.1 \pm 32.8 \\
(2.8 \pm 1.8)\end{array}$ & $\begin{array}{r}161.9 \pm 43.3 \\
(7.5 \pm 2.5)\end{array}$ \\
\hline 8 & $\begin{array}{l}2292.7 \pm 38.2 \\
(100)\end{array}$ & $\begin{array}{l}382.8 \pm 66.7 \\
(17.8 \pm 2.9)\end{array}$ & $\begin{array}{c}1418.1 \pm 66.9 \\
(66.1 \pm 2.2)\end{array}$ & $\begin{array}{l}75.7 \pm 41.0 \\
(3.6 \pm 2.0)\end{array}$ & $\begin{array}{r}171.0 \pm 56.9 \\
(8.1 \pm 2.8)\end{array}$ \\
\hline 24 & $\begin{array}{c}517.9 \pm 69.5 \\
(100)\end{array}$ & $\begin{array}{c}95.1 \pm 13.1 \\
(21.1 \pm 5.9)\end{array}$ & $\begin{array}{c}240.2 \pm 69.1 \\
(48.3 \pm 8.4)\end{array}$ & $\begin{array}{c}35.8 \pm 24.6 \\
(7.2 \pm 4.9)\end{array}$ & $\begin{array}{r}71.3 \pm 19.9 \\
(15.1 \pm 4.0)\end{array}$ \\
\hline
\end{tabular}

Data are expressed as mean \pm S.E. of 3 animals. 
Table II Composition of radioactivity in liver after a single oral administration of $\left[{ }^{14} \mathrm{C}\right]$ cabergoline to female rats $(0.5 \mathrm{mg} / \mathrm{kg})$

\begin{tabular}{cccccc}
\hline \multirow{2}{*}{$\begin{array}{c}\text { Time } \\
(\mathrm{hr})\end{array}$} & \multicolumn{5}{c}{ Radioactivity concentration (ng/eq. of cabergoline/g) } \\
(\% of radioactivity)
\end{tabular}

Data are expressed as mean \pm S.E. of 3 animals.

Table III Effect of treatment with cabergoline or phenobarbital sodium on hepatic drug-metabolizing enzymes in male rats

\begin{tabular}{lcccccc}
\hline \multicolumn{1}{c}{ Parameter } & $\begin{array}{c}\text { Vehicle } \\
0 \mathrm{mg} / \mathrm{kg}\end{array}$ & $0.05 \mathrm{mg} / \mathrm{kg}$ & $0.1 \mathrm{mg} / \mathrm{kg}$ & $0.5 \mathrm{mg} / \mathrm{kg}$ & $1.0 \mathrm{mg} / \mathrm{kg}$ & $\begin{array}{c}\text { Phenobarbital } \\
80 \mathrm{mg} / \mathrm{kg}\end{array}$ \\
& p.o. & p.o. & p.o. & p.o. & p.o. & i.p. \\
& $257.6 \pm 2.8$ & $242.8 \pm 4.6^{*}$ & $240.3 \pm 3.4^{* *}$ & $248.7 \pm 3.5$ & $243.7 \pm 1.1^{*}$ & $256.2 \pm 5.7$ \\
$\begin{array}{l}\text { Body weight } \\
\text { (g) }\end{array}$ & $4.67 \pm 0.16$ & $4.06 \pm 0.14$ & $4.04 \pm 0.13^{*}$ & $4.13 \pm 0.19$ & $4.12 \pm 0.18$ & $5.14 \pm 0.19$ \\
$\begin{array}{l}\text { Liver weight } \\
\text { (g) }\end{array}$ & $0.78 \pm 0.07$ & $0.75 \pm 0.12$ & $0.64 \pm 0.17$ & $0.68 \pm 0.10$ & $0.57 \pm 0.11$ & $2.27 \pm 0.30^{* * *}$ \\
$\begin{array}{l}\text { Cytochrome P450 } \\
\text { (nmol/mg protein) }\end{array}$ & $0.25 \pm 0.03$ & $0.39 \pm 0.02^{*}$ & $0.41 \pm 0.04$ & $0.23 \pm 0.07$ & $0.29 \pm 0.05$ & $0.58 \pm 0.04^{* * *}$ \\
$\begin{array}{l}\text { Cytochrome b5 } \\
\text { (nmol mg protein) }\end{array}$ & $1.45 \pm 0.11$ & $1.54 \pm 0.02$ & $1.65 \pm 0.14$ & $1.34 \pm 0.20$ & $1.58 \pm 0.09$ & $2.01 \pm 0.10^{* *}$ \\
$\begin{array}{l}\text { Aniline hydroxylation } \\
\text { (nmol/min/mg protein) }\end{array}$ & $5.90 \pm 0.28$ & $5.80 \pm 0.23$ & $5.47 \pm 0.69$ & $4.73 \pm 0.64$ & $3.97 \pm 0.36^{*}$ & $10.49 \pm 0.76^{* * *}$ \\
$\begin{array}{l}\text { Aminopyrine N-demethylation } \\
\text { (nmol/min/mg protein) }\end{array}$ & 5 & & & & &
\end{tabular}

Data are expressed as the mean \pm S.E. of 6 to 8 animals.

${ }^{*},{ }^{* *}$, and ${ }^{* * *}$ : Significantly different from the vehicle-group value at $\mathrm{p}<0.05, \mathrm{p}<0.01$ and $\mathrm{p}<0.001$, respectively.

Table IV Tissue distribution of radioactivity after a single intravenous administration of $\left[{ }^{3} \mathrm{H}\right]$ cabergoline to male rats (Dose: $0.5 \mathrm{mg} / \mathrm{kg}, \mathrm{n}=3$ )

\begin{tabular}{|c|c|c|c|}
\hline \multirow[t]{2}{*}{ Tissue } & \multicolumn{3}{|c|}{$\begin{array}{l}\text { Concentration of radioactivity } \\
\text { (ng eq./ml or ng eq./g) } \\
\text { Time (hr) }\end{array}$} \\
\hline & 4 & 8 & 24 \\
\hline Plasma* & $10.6 \pm 0.7$ & $8.8 \pm 1.1$ & $4.7 \pm 0.5$ \\
\hline Cerebral cortex** & 9.5 & 8.3 & 4.8 \\
\hline Striatum** & 22.5 & 19.4 & 14.0 \\
\hline Hypophysis** & 416.1 & 356.7 & 337.8 \\
\hline
\end{tabular}

* Data are expressed as the mean \pm S.E. of 3 animals. ** Data are expressed as the mean of 3 animals.

the stereocenters of cabergoline. It is likely that the metabolites maintain the stereochemistry present in the parent drug.

The composition of radioactivity in male and female rat livers consisted mostly of cabergoline and $\mathrm{FCE}^{-}$ 27395 , and the concentration-time pattern of cabergo- line was the similar in both sexes. But the concentration of $\mathrm{FCE}-27395$ was much greater in male rat liver, which can be attributed to the fact that the hepatic enzyme activity in male rats is more potent than that in female rats as generally known. The metabolites were slowly eliminated from the liver since the total concentration in male and female rat livers by 24 hours after dosing had decreased only under one third of the maximum total concentration. This finding is in good agreement with a study on the distribution after repeated oral administration of cabergoline to rats. ${ }^{13)}$

In the effect on hepatic drug-metabolizing enzymes, body weight, liver weight, and cytochrome $b_{5}$ content were significantly different from the control groups, but the change might be no biological significance because the change was not dose dependent. The hepatic cytochrome $\mathrm{P} 450$ content and the aniline hydroxylase activity were not significantly different from their controlgroup levels. Only the aminopyrine demethylase activity was observed to decrease dose-dependently, and the 1 $\mathrm{mg} / \mathrm{kg}$ cabergoline-treated group was significantly 
different from the control group in terms of this activity. To clarify the reason for this decreasing tendency of aminopyrine demethylase activity, we studied the interaction of the enzyme with aminopyrine in the absence and in the present of cabergoline in control rat liver microsomes. The metabolism of aminopyrine was suppressed by cabergoline in vitro, and cabergoline was metabolized to FCE-27395 which was the demethylderivative of cabergoline in spite of the presence of aminopyrine, but the data was not shown. And the metabolism of aminopyrine was concentration dependently inhibited by cabergoline. These facts meant that aminopyrine and cabergoline acted competitively in the demetylation toward each other, and that cabergoline was more easily metabolized than aminopyrine. Therefore, the reason for the enzyme activity repression observed in the study of the effect on hepatic drugmetabolizing enzymes is that the microsomal fraction contained cabergoline, which competed with aminopyrine for the demethylation activity. On the other hand, there was a large quantities of cabergoline and/or FCE27395 in the liver after multiple dosing with cabergoline, and these tended to be accumulated in the liver, as described before report. ${ }^{13)}$ And the study of the effect on hepatic drug-metabolizing enzymes showed the appearance of enzyme activity repression tendency seemed to be reinforced following the increase of dose of cabergoline. Our present study suggests that the accumulation of cabergoline and/or its metabolites in the liver is dependent on the dose of cabergoline. From the study of the metabolism of aminopyrine and the study of the effect on hepatic drug-metabolizing enzymes, cabergoline was likely accumulated in liver by multiple dosing, ${ }^{13)}$ but it was not effected virtually on hepatic microsomal enzymes.

And further, we must remember the regulation of P450 dependent on the hormones. ${ }^{15,16)}$ Especially, the hormones secreted from hypophysis play an important role in the regulation of drug metabolizing enzymes. It might be possible to consider the appearance of enzyme activity repression dependent on the change of the balance of hormones as higher distribution of cabergoline in the hypophysis. (This possibility is under investigation).

In the analysis of the brain metabolites, the direct analysis of rat brain tissues samples such as cerebral cortex, striatum and hypophysis was impossible, because of the low concentration of radioactivity. For this reason the analysis of each tissue was performed by pooling the same region from three rats after a single intravenous administration of $\left[{ }^{3} \mathrm{H}\right]$-cabergoline rather than oral administration. The radioactivity was distributed in cerebral cortex, striatum and hypophysis, and the composition of radioactivity in brain tissue was mainly cabergoline. As the concentration of radioactivity in the striatum and hypophysis was higher than that in the cerebral cortex, ranging between $2.3-$ fold to 2.9 -fold and be- tween 43-fold to 70-fold higher, respectively. Cabergoline crosses the blood-brain barrier and reaches dopamine receptors after intravenous administration ${ }^{5)}$. And cabergoline had the highest affinity for dopamine receptors. The distribution of radioactivity in the hypophysis was higher than the other brain tissues since cabergoline could reach dopamine receptors without crossing the blood-brain barrier in the hypophysis. Because the rate of disappearance of $\left[{ }^{3} \mathrm{H}\right]$-cabergoline from the striatum and hypophysis was very slow, these data may help to explain the long-lasting prolactin suppressing and antiparkinsonian activity. ${ }^{14)}$

\section{Reference}

1) Ferrari C., Barbieri C., Caldara R., Mucci M., Codecasa F., Paracchi A., Romano C., Boghen M., and Dubini A.: Long-lasting prolactin-lowering effect of cabergoline, a new dopamine agonist, in hyperprolactinemic. J. Clinical Endocrine Society, 63: 941-945 (1986)

2) Lera G., Vaamonde J., Rodriguez M., and Obeso J. A.: Cabergoline in parkinson's disease. Neurology, 43: 25872590 (1993)

3) Jori M. C., Franceschi M., Giusti M. C., Canal N., Piolti R., Frattola L., Bassi S., Calloni E., Mamoli A., and Camerlingo M.: Clinical experience with cabergoline, a new ergoline derivative, in the treatment of parkinson's disease, $A d$ vances in Neurology, 53: 539-543 (1990)

4) Hutton J. T., Morris J. L., and Brewer M. A.: Controlled study of the antiparkinsonian activity and tolerability of cabergoline. Neurology, 43: 613-616 (1993)

5) Strolin Benedetti M., Dostert P., Barone D., Efthymiopouls C., Peretti G., and Roncucci R.: In vivo interaction of cabergoline with rat brain dopamine receptors labelled with $\left[{ }^{3} \mathrm{H}\right] \mathrm{N}-\mathrm{n}-$ propylnorapomorphine. European J. Pharmacology, 187: 399-408 (1990)

6) Rolland R., Piscitelli G., Ferrari C., and Petroccione A.: Single dose cabergoline versus bromocriptine in inhibition of puerperal lactation: Randomised, double blind, multicentre study. B. M. J., 8: 1367-1371 (1991)

7) Webster J., Piscitelli G., Polli A., Ferrari C., Ismail I., and Scanlon M.: A comparison of cabergoline and bromocriptine in the treatment of hyperprolactinemic amenorrhea, The New England J. Med., 6: 904-909 (1994)

8) Battaglia R., Strolin Benedetti M., Mantegani S., Castelli M. G., Cocchiara G., and Dostert P.: Distribution and urinary metabolic pattern of cabergoline, a potent dopaminergic agonist, in rat, monkey and man. Xenobiotica, 23: 1377-1389 (1993)

9) Omura T., and Sato R.: The carbon monoxide-binding pigment of liver microsomes. J. Biol. Chem., 239: 2370-2378 (1964)

10) Smith P. K., Krohn R. I., Hermanson G. T., Mallia A. K., Gartner F. H., Provenzano M. D., Fujimoto E. K., Goeke N. M., Olson B. J., and Klenk D. C.: Measurement of protein using bicinchoninic acid. Anal. Biochem., 150: 76-85 (1985)

11) Imai Y., Ito A., and Sato R.: Evidence for biochemically different types of vesicles in the hepatic microsomal fraction. J. Biochem., 60: 417-428 (1966) 
12) Nash T.: The colorimetric estimation of formaldehyde by means of the hantzsch reaction. Biochem. J., 55: 416-421 (1953)

13) Nakamura S., Miyagi M., Nishiyama M., and Ujiie A.: Studies on the distribution of cabergoline (II); Absorption, distribution, and excretion after repeated oral administration to rats, and transfer into the fetus and milk of rats. Chem. Pharm. Bull., (in contribution)

14) Dostert P., Hagberg G., Battaglia R., Castelli M. G., Tocchetti P., Allievi C. and Strolin M. Benedetti: Distribution and metabolism of ${ }^{14} \mathrm{C}$-cabergoline in the rat brain. Phar- macol. Rev., (in press)

15) Yamazoe Y., Shimada M., Kamataki T., and Kato R.: Effects of hypophysectomy and growth hormone treatment on sex-specific forms of cytochrome $\mathrm{P}-450$ in relation to drug and steroid metabolisms in rat liver microsomes, Japan. J. Pharmacol., 42: 371-382 (1986)

16) Kato R., Yamazoe Y., Shimada M., Murayama N., and kamataki T.: Effect of growth hormone and transplantation of pituitary gland on sex-specific forms of cytochrome $\mathrm{P}-450$ and testosterone and drug oxidations in rat liver. $J$. Biochem., 100: 895-902 (1986) 